\title{
SIMPLE JOINT-STOCK COMPANY - A NEW TYPE OF POLISH COMMERCIAL COMPANY DEDICATED (MOSTLY) TO NEW-TECHNOLOGY ENTITIES
}

\author{
Pawet Zdanikowski*
}

\begin{abstract}
This article presents a new Polish regulation concerning the simple joint-stock company (Polish: prosta spótka akcyjna; SJSC). It is a legal form of a commercial company, dedicated mostly (but not exclusively) to new-technology entities. Its main advantage is the possibility to subscribe shares in exchange for a contribution in the form of work or services provided to the company. This will make it possible for SJSC promoters to attract investors in order to run the enterprise while maintaining control over the company and excluding personal liability for its obligations. Another characteristic is that the SJSC has no share capital. Even so, the degree of actual protection of a company's creditors does not seem lower than that provided by companies supplied with a share capital. This is because the creditors' interests are secured not only by the obligation to conduct the solvency test before paying out funds to a shareholder but also by restrictive rules of responsibility of management board members for the company's liabilities if the enforcement carried out against the company proves ineffective.
\end{abstract}

Key words: simple joint-stock company, new-technology company, share capital

Paweł Zdanikowski, Associate Professor in the Department of Commercial Law, The John Paul II Catholic University of Lublin, e-mail: pawel.zdanikowski@kul.pl, ORCID: 0000-0002-2383-5401. 


\section{INTRODUCTION}

Projects that use modern technologies, mostly related to IT, are increasingly important to the contemporary economy. The area of the economy where technology companies operate is characteristic, since a business concerning new technologies, as any innovative activity, is often riskier (the probability of economic failure is higher than in other industries). At the same time, the activity in this field requires significant financial outlays. This arises not only from high capital demand for research and implementation activities but also from strong market competition. The most competitive entrepreneurs will not be those who possess the best and most advanced technological solutions but those who can quickly acquire and maintain their clients. This, in turn, implies expenditure on marketing and advertising operations, and sometimes also investment outlays (for instance when taking over other companies that render similar services) ${ }^{1}$. Given the high capital intensity of their undertaking, the promoters would obviously like to benefit from the exclusion of personal liability for the company's obligations. Their expectations towards the investors in such undertakings are also different. The promoters of technology companies, who usually also invent the solutions they use and develop, wish to find capital support but at the same time keep their control over the company. However, they mostly cannot offer the investors anything except their own knowledge, experience or creativity. Consequently, also the structure of assets in such companies is completely different from that existing in 'conventional' companies. Immovable property, vehicles, machinery, and equipment are replaced by information, knowledge, experience, and creativity.

These demands of legal transactions cannot be satisfied by the current 'classical' form of a commercial company. The formula of a partnership is out of the question due to the personal liability of the partners. Neither the promoters nor the investors want to be held liable. The absence of personal liability of the partners is assured by the form of a company, but that is also out of the question as the possibility of contributing

1 See: Tomasz Sójka, „O potrzebie zmian unormowań niepublicznych spółek kapitałowych - uwagi na kanwie projektu przepisów o prostej spółce akcyjnej”, Przegląd Prawa Handlowego 9(2018): 13 and specialist literature cited in footnote no 3. 
work or services to the company is excluded. In fact, the expectations of technology company promoters are contrary to the traditional concept of a company.

To address the demands of the start-up community, the Polish legislator has decided to extend the Commercial Companies Code (CCC ${ }^{2}$ by a new type of company, which is the simple joint-stock company. This followed an extremely heated discussion amongst company law experts, most of whom strongly opposed the idea. The discussion was dominated by opinions that the regulation is unnecessary, as the objectives assumed by the legislator can also be achieved using other solutions; that the SJSC regulation puts the creditors of such companies at risk (no share capital, plus the fact that the company may have no assets); that it compromises the interest of potential shareholders (the shares may turn out to be worthless; no share priority limits, which may breach the rule of equal treatment of shareholders); and that it leads to chaos and breaks the cohesion of the Commercial Companies Code 3 .

Despite that, the simple joint-stock company will appear in the Polish legal system as of 1 March 2021. However, Poland is not the first country to introduce such a regulation. It already exists in France as the simplified joint-stock company (Société par Actions Simplifiée (SAS)), regulated by Articles L. 227-1 to L. 227-20 of the French Commercial Code (Code de commerce) ${ }^{4}$, and in Slovakia (Jednoduchá Spoločnost na $A k c i e$ ), regulated in $\$ 220 \mathrm{~h}$ to $220 \mathrm{zl}$ of the Slovakian Commercial Code (Obchodny Zakonnik).

The aim of this article is to briefly present the new Polish regulation and to establish whether the SJSC may actually pursue the objectives as-

2 The Act of 15 September 2000 (Polish Journal of Laws 2019, item 505).

3 See: Aleksander Kappes, „Prosta spółka akcyjna - czy rzeczywiście prosta i czy potrzebna? Uwagi do projektu nowelizacji Kodeksu spółek handlowych, wprowadzającego prostą spółkę akcyjną (projektowane art. $300^{1}-300^{121}$ k.s.h.)", Przegląd Prawa Handlowego 5(2018): 10 et seq. Similarly: Piotr M. Wiórek, „O braku potrzeby wprowadzenia prostej spółki akcyjnej (PSA) z perspektywy prawnoporównawczej”, Przegląd Prawa Handlowego, 5(2018): 4 et seq.

4 More informationon the French simplified joint-stock company, see: Michał Przychoda, „Francuska spółka akcyjna uproszczona SAS”, Przegląd Prawa Handlowego 2(2017): 53 et seq. 
sumed by the legislator, which are: to ensure an optimum legal form for the founders of new-technology companies while respecting the rights of their creditors.

\section{POSITION AND STRUCTURE OF THE REGULATION}

The simple joint-stock company has been introduced to the Commercial Companies Code (CCC) under the Act of 19 July 2019 amending the Commercial Companies Code and certain other Acts 5 . The regulations concerning the SJSC (Articles $300^{1}$ to $300^{134}$ of the CCC) cover 134 sections. It is a lot, considering that the regulations governing the limited liability company nominally cover 149 provisions, and those concerning the joint-stock company include 189 provisions.

The position of the SJSC regulations in the Commercial Companies Code has been criticized. It was raised that the new company should be regulated (if at all) by a separate legal act, just like the European company ${ }^{6}$. The integration of the SJSC regulations into the Commercial Companies Code has affected the transparency of the provisions, but it remains correct. The SJSC is a domestic commercial company, and there is no reason to claim that the comprehensive nature of the CCC as an act governing commercial companies has been impaired. This is also supported by comparative arguments. A similar solution is used by the legislators in France and Slovakia. The only difference lies in the method of regulation. The regulation concerning the Polish SJSC is generally comprehensive, only in certain matters the Code refers to the provisions on the limited liability company or the joint-stock company (e.g. Article $300^{24}$ refers to Article 212 of the CCC, which governs the right of control held by a shareholder in a limited liability company, while Article $300^{15}(6)$ of the CCC refers to the provisions on the procedure for notifying joint-stock company's

5 Polish Journal of Laws, item 1655. The original text of the Act is available here: http:// prawo.sejm.gov.pl/isap.nsf/download.xsp/WDU20190001655/O/D20191655.pdf (access date: 1.12.2019).

6 See: Joanna Kruczalak-Jankowska, „Prosta spółka akcyjna - polską superspółką?”, Przegląd Prawa Handlowego 9(2018): 27. 
creditors of the reduction in share capital). Meanwhile, the French and Slovakian Commercial Codes only regulate matters specific to the simplified joint-stock company, and in the remaining scope, they require that the provisions on the joint-stock company be applied accordingly, specifying which of those provisions shall not apply to the simplified jointstock company (see: Article L 227.1 of the French Commercial Code, and $\$ 220 \mathrm{~h}(3)$ of the Slovakian Commercial Code).

The SJSC regulation consists of six chapters: 1) Formation, 2) Rights and Obligations of the Shareholders, 3) Company Governing Bodies, 4) Amendment to the Articles and Issue of Shares, 5) Dissolution and Liquidation of the Company, 6) Civil-Law Liability. Below I briefly present the most characteristic issues.

\section{FORMATION}

The explanatory statement for the draft Act amending the CCC and introducing the SJSC emphasizes that the new legal structure has been created to address the expectations of the start-up community ${ }^{7}$. Although the SJSC was created as a legal form dedicated to companies in the new technology sector, it may be established by one or more persons to carry out any lawful business (Article $300^{1}$ of the CCC).

The articles of association may be made in a conventional manner (as a notarial deed) or electronically (in the latter case it is necessary to complete the form available in the ICT system and to sign the articles with a qualified electronic signature or using a trusted profile or a personal e-signature). If the articles are signed electronically, the shares of the first issue may only be covered by cash contribution (Article $300^{7}$ of the CCC).

7 See: Explanatory statement for the draft Act, pp. 1-4, Parliamentary Paper No. 3236, http://orka.sejm.gov.pl/Druki8ka.nsf/0/5EA8D7DC70002162C12583A70034174A/\%24File/3236.pdf (access date: 1.12.2019). 
In accordance with Article $300^{2}(2)$ of the CCC, non-cash contribution aimed at covering shares may be any contribution of financial value, in particular the provision of work or services. It seems that this is the most important regulation concerning SJSC, which makes this legal form useful to technology companies. From the point of view of SJSC promoters, own work of shareholders contributed to the company is an optimum solution to commercialize their intellectual capital (knowledge, skills, experience, and creativity). However, the promoter's option to make such contribution generates risks both to the company investors and to its creditors. For the investors, the risk lies in overestimating the value of the contribution. There is no guarantee that the shareholder subscribing shares for such a contribution will be as effective and creative as the other investors expect. This risk, however, is an integral part of the SJSC nature, which the investors should be aware of. For the creditors, the risk lies in the fact that the contribution in such a form does not increase the company assets from which a creditor could satisfy their claim (work or services provided by shareholders cannot be subject to enforcement proceedings carried out against the company).

The valuation of contributions in kind depends on the promoters' decision. Since the shares have no par value, it is the promoters who decide about the value each contribution represents to the company. This value is reflected in the issue price for the shares the company offers to its shareholders.

\section{PROTECTION OF CREDITORS}

Traditionally, the basic tool for protecting the creditors of a continental company was the concept of share capital. It became a subject of strong criticism at the end of the 1990s. Critical opinions intensified once the European Court of Justice had allowed (as a sign of freedom of establishment) transferring the actual registered office of a company incorporated in one European Union Member State to another state ${ }^{8}$. Of course, this did not

8 See judgments of 9 March 1999, C-212/97 Centros; of 5 November 2002, C-208/00 Überseering; of 30 September 2003, C-167-01 Inspire Art, all available on 
concern the migration of companies between continental European countries where regulations concerning the minimum capital were similar, but it was about incorporating a company in the United Kingdom and carrying on business in another EU country. This all happened because British law did not require shareholders in private companies to contribute a specified part of equity capital at the stage of company formation. In consequence, many companies incorporated in the United Kingdom actually operated in the other EU Member States. That development was subject to extensive doctrinal disputes, in both European and Polish literature 9 It called to eliminate the share capital due to the ineffective protection of creditors and excessive restrictions. The massive migration of companies to the United Kingdom exerted pressure on legislators in continental Europe who waived the minimum capital requirements ${ }^{10}$. Several EU countries have introduced significant amendments to their regulations on limited liability companies, involving a total absence or considerable reduction of share capital required. Such regulations were adopted particularly in Germany, the Netherlands, Luxembourg, Italy, the Czech Republic, Portugal and Finland ${ }^{11}$.

Share capital is not (and has never been) an effective measure for protecting the interests of company creditors. It is not an inviolable deposit which the company would be required to protect for the benefit of its

https://curia.europa.eu; see also: Mathias Habersack, Dirk. A. Verse, Europäisches Gesellschaftsrecht, Munich: C.H. Beck, 2011, 16-35; Marieke Wyckaert, Filip Jenne, "Corporate Mobility”, In: The European Company Law. Action Plan Revisited, ed.: Koen Geens, Klaus J. Hopt, Leuven: Leuven University Press 2010, 306-311.

9 See, inter alia: Arkadiusz Radwan, „Sens i bezsens kapitału zakładowego - przyczynek do ekonomicznej analizy ustawowej ochrony wierzycieli spółek kapitałowych", In: Europejskie prawo spółek, vol. II, Instytucje prawne dyrektywy kapitałowej, part II, ed. Mirosław Cejmer, Jacek Napierała, Tomasz Sójka, Cracow: Zakamycze, 2005, 23-100, and the literature referred to therein.

10 See: John Armour, Wolf Georg Ringe, "European Company Law 1999-2010: Renaissance and Crisis", Law Working Paper 175 (2011): 16 https://ssrn.com/abstract=1691688 (access date: 1.12.2019).

11 See more: Cécile Bervoets, Eva-Désirée Lembeck, Die „GmbH Light“ - ein Trend in Europa, Steuer und Wirtschaft International - Tax and Business Review 7 (2004): 355-363. In Polishliterature, see: Piotr M. Wiórek, O braku potrzeby wprowadzenia prostej spółki akcyjnej (PSA) z perspektywy prawnoporównawczej, 4-5. 
creditors. Based on rigid financial criteria, it only binds company assets, irrespective of the company's actual economic standing. Share capital is also not a theoretical structural component of a company. Therefore, it may be eliminated. The only question concerns alternative protective measures for creditors $^{12}$.

No share capital (kapitat zaktadowy) is required in the structure of the SJSC. It is replaced by equity capital (Polish: kapitat akcyjny), but its functions differ essentially from those of the share capital. The equity capital is indeed composed of contributions made by shareholders, but only of those which may be recognized in the balance sheet (so excluding inalienable rights and contributions involving the provision of work or services). Minimum equity capital has been set at PLN 1, and changes in its amount are not subject to the provisions concerning amendments to the articles of association (Article $300^{3}$ of the CCC). The equity capital is also supported by compulsory write-offs on profit ( $8 \%$ of profit for each financial year, until reaching $5 \%$ of total company liabilities recognized in the approved financial statements for the last financial year - Article $300^{19}$ of the CCC). At the same time, the equity capital may be used for payments made to shareholders (dividend, payment on the redemption of shares, covering the price for own shares acquired by the company). The admissibility of all these pay-outs depends on the result of the solvency test. Following Article $300^{15}$ (4) to (5) of the CCC, disbursement to shareholders shall be allowed unless it causes the company to lose, in normal circumstances, its capacity to settle the financial liabilities due within six months from the date of disbursement. This is assessed independently by the company management board. The lower limit of discretionary powers as to the disbursements is set at $5 \%$ of the total liabilities of the company, as recognized in the approved financial statements for the last financial year. If the management board wish to pay out a higher amount, they must conduct the so-called notification procedure (Polish: postępowanie konwokacyjne), which consists in notifying company creditors of the reduction in equity capital and checking whether they do not object (Article $300^{15}$ (4) of the CCC).

12 See more on the matter: Michał Żurek, Reforma regulacji prawnej kapitału zakładowego spółki z ograniczoną odpowiedzialnością. Problematyka ochrony wierzycieli, Warsaw: CH Beck, 2018, 113-203. 


\section{SHARES}

Shares in a joint-stock company do not take the form of documents (Article $300^{29}(1)$ of the CCC) and must be recorded in the shareholders' register (Article $300^{30}(1)$ of the CCC), maintained by an entity entitled to keep investment accounts under the Act on Trading in Financial Instruments, and by a notary. The register is maintained in electronic form and may exist as a distributed and decentralized database (Article $300^{31}$ of the CCC), that is using blockchain technology. Shares in an SJSC are obviously transferable but may not be used for organized trading. Their alienation requires the form of a document, under pain of nullity (Article $300^{36}$ of the CCC), and the mere act of alienation or encumbrance of shares is of a real nature, as it is effective only upon making an entry in the shareholders' register (Article $300^{37}$ of the CCC), unless the shares are transferred by operation of law (such as in succession).

Similarly to the limited liability company, the articles of the simple joint-stock company may make the disposal of shares conditional on the consent provided by the company, or restrict it otherwise. If the shares have not been fully covered, their alienation is - by statute - conditional on the company's consent. The company may refuse such consent, not having to identify any other acquirer. If consent is granted, the acquirer holds joint and several liabilities with the alienor for making the residual part of the contribution.

Unlike the regulations concerning the joint-stock company, where the succession of shares may not be limited, the articles of the simple joint-stock company may restrict or exclude the successors of the deceased shareholder from joining the company. In this case, the articles of association should set out the conditions for paying off the successors not joining the company, on pain of the restriction or exclusion being ineffective. The payment due to the successors should take into account the ratio of the value of the contribution paid into the company to the value of the contribution unpaid. However, in the event of the death of a shareholder who held shares taken up for a contribution involving work or services which has not been fully paid, his/her successors may join the company only upon the company's consent, unless the articles of association provide otherwise (Article $300^{41}$ of the CCC). 


\section{ISSUE OF NEW SHARES}

Recapitalization of the company at a later stage of its operation does not take place by increasing its equity capital but by issuing new shares. As a rule, a resolution on the issue of shares amends the articles of association and requires $3 / 4$ of votes (Article $300^{98}(2)(1)$ of the CCC), unless the articles already provide for the issue of shares and set the maximum number of shares and the date when they may be issued (Article $300^{103}$ of the CCC). The resolution on the issue of shares should also specify the issue price. Therefore, the value of contribution in kind is also at this stage determined by shareholders, even though in this case it is decided by the majority of votes. The restriction or exclusion of pre-emptive right is also permitted, but the appropriate resolution requires a $4 / 5$ majority of votes (Article $300^{106}(2)$ of the CCC).

Shares are taken up under a share subscription agreement, by which the company undertakes to issue shares to the subscriber, and the subscriber undertakes to contribute. The share issue resolution and the share subscription agreements are notified to the register along with a statement by all management board members that the contributions to cover the new shares have been paid in the part provided for in the share issue resolution or the share subscription agreements, and a statement by all management board members specifying the amount of equity capital. The shares shall be issued upon entry into the register.

Aside from the issue of new shares on general terms, the CCC offers two solutions already known from the regulations on the joint-stock company, that is the authorisation for the management board to issue shares (which in the joint-stock company is called 'target capital') and the issue of shares which depends on certain conditions (which in the joint-stock company is known as 'conditional increase of share capital'). The former solution consists in authorising the management board to issue shares, this authorisation extending for not more than five years. The management board may exercise the authorisation by carrying out one or several share issues in that period, provided that the scope of the authorisation may not exceed one fourth of the total number of shares issued by the company as at the date the authorisation was granted. The authorisation for the management board to issue shares may be granted for subse- 
quent periods not longer than five years. The granting of the authorisation requires an amendment to the articles of association (Article $300^{110}$ of the CCC). If this is the case, the management board resolution, adopted within the scope of the authorisation added to the articles, substitutes the resolution on the issue of shares passed by the general meeting. The management board decides on all matters related to the issue of shares, unless the provisions of a relevant chapter of the Code or the authorisation granted to the management board provide otherwise (Article $300^{112}$ of the CCC). The purpose of the conditional issue of shares is to allow acquisition of shares by the holders of convertible bonds or bonds with pre-emptive rights, persons who acquired such rights under an agreement made with the company, and holders of subscription warrants (securities issued by the company providing holders with the right of subscription for shares). Unlike the general terms, the rights under shares forming part of the contingent issue are not acquired upon entry into the National Court Register but upon entry into the shareholders' register (Article $300^{118}$ of the CCC).

\section{RIGHTS AND OBLIGATIONS OF THE SHAREHOLDERS}

The structure of two essential rights of the shareholders (the right to profit and dividend and the right to vote) has remained the same as in the joint-stock company and limited liability company. In consequence, dividend is distributed in proportion to the number of shares, unless the articles of association provide otherwise (Article $300^{15}$ (3) of the CCC). Similarly, the right to vote is attributed to each share (Article $300^{23}$ of the CCC). Rights are enjoyed by the shareholders under their shares, and do not depend on the type of contribution. From this point of view, the legal position of the shareholders who have made contributions to equity capital and those who have made contributions which cannot be recognised in the balance sheet remains identical.

An important advantage of the SJSC over other types of companies is considerable freedom of shareholders when shaping their membership rights, especially as to the possibility to deviate from the proportionality principle, which makes the scope of shareholder rights conditional on 
the ratio of shares held to the total number of shares. Consequently, it is allowed to create non-voting shares, which must be preferred as to dividend (Article $300^{27}$ of the CCC), and to set privileges related to the shares or shareholders, while the CCC imposes no restrictions on the scope of these privileges (other than in the limited liability company or the jointstock company).

The legislator has also introduced the shareholders' right to individual control of the company, which had previously applied only to the limited liability company. An SJSC shareholder may demand the management board to provide information and explanations and to give access to the company documents (Article $300^{24}$ of the CCC in conjunction with Article 212 of the CCC).

The SJSC regulation also allows another concept, previously applied in Polish law only to the limited liability company, that is the expulsion of a shareholder. An SJSC shareholder may be expelled only for good reason, under a court judgment or at the request of a shareholder or shareholders representing more than a half of the total number of votes (the articles of association may, however, restrict this right enjoyed by a shareholder or shareholders by setting a higher requirement applicable to the proportion of votes required - Article $300^{49}$ of the CCC).

In the SJSC, it is also permitted to apply to court for a judgment on resignation of a shareholder at his/her request, if there is a good reason grounded on the relationships between the shareholders or between the company and the resigning shareholder, which causes gross detriment to the resigning shareholder (Article $300^{50}$ of the CCC). This implements the right to leave the company, as demanded by legal doctrine ${ }^{13}$. Unlike in partnerships, a shareholder in a company cannot terminate the articles of association. Consequently, in extreme cases, particularly in the event of a corporate conflict, a shareholder may become 'trapped' in the company. The permission to take judicial action for leaving the company will secure the interests of such trapped shareholders.

13 See: Arkadiusz Radwan, Ius dissidentium. Granice konsensusu korporacyjnego i władzy większości w spółkach kapitałowych, Warsaw: CH Beck, 2016, 616. 


\section{GOVERNING BODIES}

Until the provisions on the simple joint-stock company is being entered into force, the Polish commercial companies law uses the dualistic model of corporate governance. It assumes that the company affairs are handled by the management board, while the supervisory board, being a separate body, supervises the company operations. The SJSC regulations introduce the option to create a monistic model of corporate governance, also known in other legal systems, by establishing a board of directors. Therefore, in the SJSC it is possible to establish either a management board and (optionally) a supervisory board or a board of directors. Of course, either of the two models involves the general meeting of shareholders.

In the dualistic model, the management board, composed of one or more members who, as a rule, is appointed by the general meeting, represents the company and manages its affairs. Supervision is exercised by the supervisory board, composed of at least three members, who are also appointed by the shareholders.

In the monistic model, the management of company affairs and the representation and supervision of the company remain with the board of directors. It consists of one or more directors, who are appointed and removed by the shareholders (Article $300^{73}$ of the CCC). However, the articles of association or the rules of procedure or a resolution of the board of directors may delegate all or a part of business management operations to a single director or certain directors (executive directors). In such a case, the directors not being executive directors (so the non-executive directors) supervise the management of company affairs on an ongoing basis. To carry out business management operations, it is possible to appoint an executive committee, composed only of the executive directors. In this case, the special duties of the non-executive directors include assessing whether the management board reports on company operations and the financial statements for the previous financial year are made correctly and reliably and providing the general meeting with an annual written report on the results of such assessment. To ensure permanent supervision over the management of company affairs, it is possible to establish a board of directors committee, composed only of the non-executive directors (Article $300^{76}$ of the CCC). 
The regulations concerning the general meeting of shareholders in the SJSC are very similar to those regarding the shareholders' meeting in the limited liability company. The meeting is generally convened by the management board, but the extraordinary general meeting may also be convened by the supervisory board if it deems it appropriate. The right to demand convention of the meeting lies also with the shareholders representing at least one-twentieth of the total number of votes or shares. If the management board rejects the demand, the shareholders may apply to the court of registration for granting authorization to convene the meeting independently (Articles $300^{84}$ to $300^{85}$ of the CCC).

The right to participate in the meeting is enjoyed by a shareholder entered into the shareholders' register as of the date falling three days before the date of the general meeting (Article $300^{91}$ of the CCC).

The meeting may also be held electronically if so permitted by the articles of association, and is valid regardless of the number of shares represented (Article $300^{92}$ and Article $300^{94}$ of the CCC). As a rule, resolutions are passed by an absolute majority of votes (Article $300^{98}$ of the CCC).

\section{DISSOLUTION AND LIQUIDATION \\ OF THE SIMPLE JOINT-STOCK COMPANY}

Generally, the SJSC is dissolved and liquidated just like the limited liability company and the joint-stock company. However, the provisions on the SJSC introduce a concept previously unknown to Polish companies. It is the possibility for a specified shareholder (acquiring shareholder) to acquire all the company's assets. This is regulated in Article $300^{122}$ of the CCC. The acquisition is conditional mainly on a relevant resolution by the general meeting, passed by a $3 / 4$ majority of votes in the presence of shareholders representing at least half of the total number of shares. Then the resolution is submitted to the registry court, which announces it and calls the creditors to lodge objections. The final decision is made by the registry court, which also examines any objections filed by the creditors. Another condition for the consent to the acquisition of assets is that the shareholder must demonstrate that, in all probability, the acquisition will cause no detriment to company creditors or shareholders, and any ob- 
jection filed by a creditor must be deemed unsubstantiated. If an objection is lodged, the registry court shall decide to hold an open sitting. Immediately after the decision allowing the acquiring shareholder to take over the company assets becomes final and binding, the management board shall file a request to delete the company from the register. As of the date of such deletion, the acquiring shareholder shall assume all the rights and obligations of the deleted company.

Shareholder's option to acquire the company certainly makes the SJSC more attractive. In addition to the uncomplicated method of company formation, the convenient conditions of winding down company operations also favourably affect the efficacy of a given type of commercial company. The regulation is not free of doubts (such as those regarding the procedure and way of resolving creditors' objections ${ }^{14}$ ), but most of them will be dispelled by the judiciary. The prescribed measures for protecting other shareholders and creditors seem to be sufficient. The registry court may condition the shareholder's acquisition of assets on establishing collateral, and the acquisition resolution may be challenged on general terms.

\section{LIABILITY OF MANAGEMENT BOARD MEMBERS}

For the SJSC, the legislator has also introduced the concept of liability of management board members for the company's obligations, which had previously been characteristic only to the limited liability company. This occurs if enforcement carried out against the company turns out to be ineffective. A management board member may be released from such liability if he proves that a bankruptcy petition was filed in due time or that, at the same time, a decision was made to initiate the restructuring proceedings or to approve an arrangement in the proceedings for arrangement approval, or that he is not culpable for the failure to file the bankruptcy petition, or that the creditor has suffered no harm despite the failure to file the petition for bankruptcy and to make the decision to initiate the re-

14 These are raised by Marcin Podleś, Lidia Siwik, „Likwidacja spółek z perspektywy projektowanej regulacji prostej spółki akcyjnej”, Przegląd Prawa Handlowego 9(2018): 46. 
structuring proceedings or to approve an arrangement in the proceedings for arrangement approval (Article 300132 of the CCC).

Personal liability of management board members for the company's obligations, if enforcement against the company's assets proves to be ineffective, seems to be a rather harsh solution from a comparative point of view. Under Polish law, however, it is not unusual. Such liability is provided by Article 299 of the CCC with a limited liability company. This does not affect the popularity of the limited liability company, which is the most numerous commercial company in Poland.

\section{CONCLUSIONS}

The modern concept of a company was not formed until the 19th century. This probably happened so late because it had been widely accepted for centuries that those who wish to run a business should hold personal liability for the related obligations. However, the Industrial Revolution and the associated demand for capital and optimum forms of running a business caused a departure from those assumptions and led to the creation of new legal forms of companies: first the joint-stock company and then the limited liability company. The modified axiology of commercial companies law assumed that since the shareholders are not liable for the company's obligations, they should supply the company with assets, which will then be used to satisfy the company's creditors (if still possible). Consequently, the possibility to provide work or services as a contribution to a company has been banned (the idea was that the object of contribution should have a real value to the creditor, that is - it should be enforceable for the creditor's benefit).

The obligation to make a contribution and the prohibition to return it has become the justification for the absence of personal liability of shareholders for the company's obligations. It was (rightly) claimed that a regulation that allows shareholders to benefit from the exclusion of personal liability and imposes no restrictions on them would be wrong. This assumption was pursued by the concept of share capital. On the one hand, it required the shareholders to engage a minimum but serious capital in their joint undertaking, and on the other hand, it blocked the assets for 
the shareholders by banning any disbursements to them if the value of the assets fell below the value of the share capital

More than 150 years after the concept of a company was shaped, very serious changes were again experienced in the global economy. These changes can be compared to a certain extent with the economic changes that occurred at the end of the 18th century. The development of technology and the possibility to provide, on a mass scale, the services which are based on information processing and related technologies have increased the importance of 'intellectual capital'. The classical form of company, as a way of associating an idea and a capital, is no longer sufficient when confronted with the capital intensity of start-ups and the concern about the liability for the company's obligations justified by the scale of the business.

The emergence of the SJSC means that we deal with at least a partial modification of the concept of what 'a company' is. It is no longer based on combining the lack of personal liability and the prohibition to make a contribution in the form of work or services. In consequence, the promoters of SJSCs, mostly being the originators of the whole enterprise, will be able to keep control over the company by contributing intellectual capital'. This legal form also offers flexible methods of financing at a later stage of operation, by issuing bonds or subscription warrants convertible into bonds, as well as by offering a convenient management model (the option to establish a board of directors) and simplified methods of liquidation.

All this makes the SJSC a potentially effective legal form of business, not only for technology companies. We may rather expect that it will be used on a wider scale, and even predict that the number of new limited liability companies will decrease due to the possibility to set up an SJSC. This is because the SJSC is, in terms of its features, more similar to the limited liability company than to the joint-stock company.

There are obvious concerns related to the elimination of share capital and the new forms of protecting creditors' interests. The absence of minimum capital requirement and the solvency test used as an essential instrument to restrict money transfers between the company and its shareholders seem to impair creditor protection. However, did a fixed share capital protect creditors more effectively? Particularly in the Polish environment, where the minimum share capital was set at PLN 5,000 (slightly over EUR 1,000). Therefore, it seems that with the solvency test, com- 
bined with compulsory write-offs on equity capital and personal liability of management board members for company's obligations, the effective degree of creditor protection will neither be higher nor lower than the degree provided by share capital, but it will be more efficient for companies.

\section{REFERENCES}

Armour, John, Ringe, Wolf Georg. 2011. "European Company Law 1999-2010: Renaissance and Crisis". "Law Working Paper 175/2011", December 1, 2019, https://ssrn.com/abstract=1691688.

Bervoets, Cécile, Lembeck, Eva-Désirée. 2004. "Die „GmbH Light" - ein Trend in Europa, Steuer und Wirtschaft International“. „Tax and Business Review“ 7: 365-363.

Habersack, Mathias, Verse, Dirk. A. 2011. Europäisches Gesellschaftsrecht. Munich: $\mathrm{CH}$ Beck.

Kappes Aleksander. 2018. „Prosta spółka akcyjna - czy rzeczywiście prosta i czy potrzebna? Uwagi do projektu nowelizacji Kodeksu spółek handlowych, wprowadzającego prostą spółkę akcyjną (projektowane art. $300^{1}-300^{121}$ k.s.h.)". „Przegląd Prawa Handlowego” 5: 10-16.

Kruczalak-Jankowska, Joanna. 2018. „Prosta spółka akcyjna - polską superspółką?”. „Przegląd Prawa Handlowego” 9: 27-28.

Podleś, Marcin. Siwik, Lidia. 2018. „Likwidacja spółek z perspektywy projektowanej regulacji prostej spółki akcyjnej”. „Przegląd Prawa Handlowego” 9: 42-46.

Radwan, Arkadiusz. 2005. „Sens i bezsens kapitału zakładowego - przyczynek do ekonomicznej analizy ustawowej ochrony wierzycieli spółek kapitałowych". In: Europejskie prawo spółek, vol. II, Instytucje prawne dyrektywy kapitałowej, part II, ed.: Mirosław Cejmer, Jacek Napierała, Tomasz Sójka, 23-100. Cracow: Zakamycze.

Radwan, Arkadiusz. 2016. Ius dissidentium. Granice konsensusu korporacyjnego i władzy większości w spółkach kapitałowych, 616. Warsaw: CH Beck.

Sójka, Tomasz. 2018. „O potrzebie zmian unormowań niepublicznych spółek kapitałowych - uwagi na kanwie projektu przepisów o prostej spółce akcyjnej”. „Przegląd Prawa Handlowego" 9: 12-18.

Wiórek, Piotr M. 2018. „O braku potrzeby wprowadzenia prostej spółki akcyjnej (PSA) z perspektywy prawnoporównawczej”. „Przegląd Prawa Handlowego" 5: 4-9. 
Wyckaert, Marieke. Jenne Filip. 2010. "Corporate Mobility”. In: The European Company Law. Action Plan Revisited, ed.: Koen Geens, Klaus J. Hopt, 306-311. Leuven: University Press.

Żurek, Michał. 2018. Reforma regulacji prawnej kapitału zakładowego spółki z ograniczoną odpowiedzialnością. Problematyka ochrony wierzycieli, 113-203. Warsaw: CH Beck 
